\title{
Nammalvar's Tamil A Hundred Measures of Time
}

\section{TRANSLATOR'S NOTE AND TEXT}

The hundred verses of A Hundred Measures of Time (as Archana Venkatesan has named the Tiruviruttam) adumbrate the medieval genre of kovai-literally, a chain or necklace-in which poems ostensibly suited to the old interior (akam) grammar of love and its landscapes, including the progression from the moment of falling in love in the mountains to the inevitably dissonant marriage of the couple in the plains, actually celebrate a deity mentioned obliquely in each verse. In A Hundred Measures of Time, these two heroes-the lover of the akam tradition and Lord Vishnu, here called Kannan (Tamil for Krishna), with the entire repertoire of his divine exploits-are largely merged. The landscape is that of Venkatam mountain (Tirupati), thus suited to the phase of stolen premarital union in the akam grammar; but most of the poems are suffused with the sorrow of longing and absence. In terms of style, metrics, and language, A Hundred Measures of Time comprise a new departure for classical Tamil. Nammalvar, probably an eighth-century poet from the far south of the Tamil country, is the central figure among the series of twelve Alvars-poet-devotees who created the canon of Tamil Vishnu bhakti. Here I offer the six opening verses of Nammalvar's poem, as well as verse 11.

A HUNDRED MEASURES OF TIME BY NAMMALVAR (VERSES 1-6, 11)

Knowledge that is a lie,

bad living,

foul body-

to give us breath

so we won't have to suffer all this

you've been born

in this womb and that. 
Lord of the gods,

hold fast to your body,

listen, now,

to your servant's prayer. (1)

Like fish flashing in a deep pool, her eyes, streaked with red, well up with dizzy tears.

Blessings on her and her dark curls that weave a garland of love for two feet the ancient gods revere: his, Kannan's, black as a cloud bursting with rain. (2)

It has followed after the great bird aflame with anger that he rides, as the gods bow low, that lord of cool sweet basil and a fiery discus,

but now, when my lonely heart sees the gentle girl of the cowherds ${ }^{1}$ with their bamboo flutes, and Earth, and Splendor, these goddesses who follow him as a shadow, it might just stop and stay with them. Then again it might come home to me. (3)

My lonely heart was lost once before-to his great bird.

Soon this heart will be lost again to his cool and fragrant basil.

We, in any case, are without it. As for you, frigid wind poisoned with basil from his crown 
after he savored the nipples

of the false and angry demoness,

is it natural that you steal inside

to freeze our very breath? (4)

The freezing north wind that makes us shiver

has put aside its frigid nature

and now, here,

rages with fire,

as this wide-eyed girl

in her sorrow

weeps cold tears, cold

as sweet basil.

For the sake of her black beauty,

the brilliant scepter in the hands

of the lord dark as freezing rain

today

has twisted and bent. (5)

Sinuous vine bearing darts

deadlier than arrows and bent bows,

she is Death, lurking in ambush

to strike down with love

this slayer of demons as he comes riding

his swift bird.

And you: look at her, look

to your own lives

inside this world. (6)

Rare is that vision,

Oh you who are radiant

as the heaven of Kannan, yet

he has gone away, gone many miles

in search of wealth,

or so it seems, though the whole world

was there in your eyes, wide as fish,

as the palm of a hand,

dripping tears rare as pearl,

fugitive as gold. (11) 


\section{"YOU CAME SO THAT WE MAY LIVE"}

\section{Anand Venkatkrishnan (Near Reader)}

The subject of this chapter is seven stanzas David Shulman has translated from A Hundred Measures of Time, a collection of one hundred poems by the Tamil Vaishnava poet Nammalvar. My task is not to provide the full context of Nammalvar's poem, but instead to read Shulman's Nammalvar: first his saint-poet (Alvar), and then only ours. Of course, one does not simply read Nammalvar. One hears, absorbs, drowns. To hear the Alvar's poems is to be suffused with a sense of God's simultaneous presence and absence; he is here, in the innermost heart, and yet hidden. The only way to recapture him is to sing together, in a community of lovers. Shulman's translation offers a version of this community, now one of readers. At the same time, it succeeds in disorienting the reader, leaving open the puzzles in Nammalvar's own jagged, searching poems. By revealing that wonder, that strangeness, Shulman's translation urges us to find our own Alvar.

In the first line of the first stanza, Nammalvar's opening words can also be translated as "false knowledge." Instead of the adjective "false," Shulman places the noun "knowledge" in apposition with the word "lie," a more literal translation of the Tamil substantive. Why has he made this choice? Everyday life in a physical body involves learning, from birth onward, but the lessons are a lie: that loved ones will not be lost, that suffering will not touch us, that we will never die. For the fragile, foul body only makes for bad living. The Lord, however, takes on precisely such bodies, incarnating again and again, to give us the breath of life. So, in Shulman's rendering, we pray: come, keep your body, so that we may truly live.

Singing the body of God is not exclusively Nammalvar's concern. Shulman, too, has given much attention to the process. In his studies of the eighteenth-century South Indian musician Muthuswami Dikshitar, Shulman explores the techniques of "auralization" in Dikshitar's compositions. As an initiate of the Srividya ritual and cosmological tradition, which reconstructed the body of the goddess through complex syllabic utterances, Muttuswami Dikshitar attempted to turn incantation into notation, the phonic into the symphonic. In other words, he made music the method by which the goddess could be invoked. Be it Dikshitar's goddess Abhayamba, invoked in the interstices of language and melody, or Nammalvar's Vishnu, visualized by a community of extravagant beholders, Shulman translates their manifestation for us into his own rhythmic writing.

This first stanza also captures the classic Alvar tension of embodied life: as devotees, their experience of Vishnu supersedes all, but as human beings they cannot escape their own mortality. What Nammalvar does in this stanza, as Shulman reads it, is to praise God for refusing to let humans suffer alone. He encourages God to keep at it: take this, our body, in memory of us. You've done it in the past, in the stories we tell about you, why not now? Shulman's subtle switch to 
the imperative mood toward the end ("hold fast to your body"), before the prayer itself ("listen"), brings out the implicit content of that prayer.

The next six stanzas rush breathlessly through a startling tableau of love: visible, elusive, throbbing, severe. In his brief introduction, Shulman remarks that the two lovers of the classical Tamil love poem merge here. In places one can detect a third voice, not fully omniscient, a shadow over our lovers, like Vishnu's consorts in the third stanza. The heart, too, is its own subject, not completely belonging to the speaker who claims it. This instability of the self, the porous boundary between self and other, is another of Shulman's classic preoccupations. Here, as in many of his translations, he exemplifies that ambiguity.

Stanzas two and three oscillate between a detached, sympathetic observer, and a more emotional, jealous one. Both are witnesses to women's love for the dark one, Kannan; one blesses it, the other curses it. Perhaps, in the second stanza, we are being introduced to the speaker in the third: the woman whose eyes "well up with dizzy tears." In the third she addresses her lonely heart, but in Shulman's version she is not sure if it belongs to her anymore. What will the heart, this thing outside of me, do now? It has already chased after one who is alternately cool and hot and has to watch while he makes love to his goddess girlfriends, stuck to him like a shadow. Will it join them, or will it come back? And who am I, now, to whom it would return?

In keeping with the poem's formal constraints, Shulman begins the next stanza with the compound word that ends the previous, that "lonely heart." It's done this before, the speaker says, running behind Vishnu's great bird Garuda. The slightest whiff of his basil, and I won't have a heart left to be stolen. Shulman deftly redeploys this verb of thieving as the forlorn speaker addresses the cool breeze: as for you (in Tamil, the accusation is direct and sharp), you "steal inside" and freeze our breath with the poisonous fragrance you carry. The fragrance is poisonous, of course, for two reasons: first, it wafts from the head of Krishna as he sucks the poison from the demoness Putana's breasts; second, it embitters and mocks an already empty heart.

In the fifth stanza, the tempest of love's emotions is once again reflected in the elements, as they not only shuttle rapidly between extreme heat and extreme frigidity, but exchange properties as well. The motif of contradictory properties is an old one in South Asian art. In Kalidasa's Recognition of Shakuntala (3.11), the infatuated king Dushyanta lashes out at both the god of love and the moon, for their supposedly soothing qualities:

That your arrows should be flowers, and the moon have cooling rays: both are patently false for those in my sort of condition. 
The moon ejects fire

with every icy beam,

and as for you, your flower power

becomes a thunderbolt!

The motif is long-lasting, too; a famous song from the Hindi film Manzil (1979) begins: "The monsoon rain pours down / kindling a flame in the heart. / In this season, so drenched with rain / how can such a fire blaze?" To return to the fifth stanza, the north wind from the previous stanza discards its coolness and "rages with fire." At the same time, the lonely woman "weeps cold tears." While tears of love are generally hot, in the poem her tears match the complexion of the lord, "dark as freezing rain." This is not an accidental connection; South Asian poetry frequently maps the body onto the world and vice versa. In the poems of the sixteenth-century Braj poet Surdas, for example, the tears of the forlorn Radha, as she mourns the absence of her lover Krishna, generate a landscape all their own. Radha's tears are intended to melt Krishna's hard heart. In Nammalvar's verse, however, it is not his heart, but his scepter that has "twisted and bent." The dark, unsettling imagery here is carried into what is undoubtedly the most striking of Shulman's translations, in stanza 6.

Undaunted in her efforts to win back her capricious beloved, the unnamed woman is now called "Death," wielding the scepter not of final judgment, but of the god of love. She is a "sinuous vine," more dangerous than scattered arrows and broken bows. Her elasticity allows her to coil up and whip out, as she lies in wait for a different killer, the slayer of demons. Suddenly, we are the ones being addressed: "Look at her," says the chorus-like observer, and "look to your own lives inside this world." The shift in modality jolts the listener. We have until now been voyeurs of a fairly common vignette in the context of Tamil love poetry: a lonely heart pines for a majestic beloved, teasing, heroic, beautiful. Her longing, like Radha's tears, is mapped onto certain key words and spaces. Shulman has already called attention to the hills as the landscape of premarital love. However, the emotional storm that has been building since the second bursts into a violent conclusion in the sixth, signaled immediately by Shulman's brilliant use of the word "sinuous" and its sinister sense. It is a shocking scene, the woman no longer pining alone but "lurking in ambush," ready "to strike down with love" the object of her affection. And as we survey the grisly portrait, the speaker sidles up behind us, whispering "And you," expertly marked off by Shulman in a separate stanza. You may think this is about someone else, but watch out: God has a way of pulling you out of yourself.

There is plenty to say about the style, metrics, and language of the Hundred Measures of Time that marks a departure for classical Tamil. I confine myself to the arresting content of these stanzas in Shulman's rendering. No longer are we suffused with the anticipation and excitement of union. No longer is the affair innocent, playful, optimistic. Love is deadly, eerie, disorienting. So disorienting, in fact, that by stanza 7, in Shulman's translation, we see language itself disassembling, 
self-destructing. Initially the subject is a rare vision-of whom? —addressed to a radiant unknown. There is an abrupt shift to Kannan, the Tamil name for Krishna, traveling in search of wealth. Just as quickly, the poem returns to the unknown addressee. The last few lines zoom into the speaker's wide-open eyes, dripping priceless jewels. Through the mist of tears we might discern the following scene: a woman wonders why Krishna, like some everyday merchant, would go anywhere else to find what is right in front of him, "though the whole world," in Shulman's moving translation, "was there in your eyes." These are tears not of longing but of desperation. If he will not stay put even when we are together, then what is the point of love?

Nammalvar's poems, Shulman says, are meant to take our breath away. This breath is precious, precarious, dependent. God breathes into us, and love pumps the bellows. Being a person the Tamil way, as it appears in these poems, is to live in love. This is a frightening prospect, but the reward is unsurpassed. Whether or not we can experience Nammalvar's breathlessness, thanks to this translation, we can follow him some way into the depths.

\section{TAKING THE MEASURE OF A HUNDRED MEASURES}

\section{Andrew Ollett (Far Reader)}

I admit to being at a complete loss when I first tried to respond to these verses from A Hundred Measures of Time. It was not just that they come from a world with which I am quite unacquainted, or that they appeared to deal with topics from which I have, for a long time, kept my distance. It was the feeling that whenever an image, conceit, or narrative began to emerge, it immediately slipped away, "like fish flashing in a deep pool." Was it really the case that texts like this stood silent and unyielding before any reader who was not initiated into the protocols of reading in the tradition to which it belonged? I decided to try reading it as if it were a Sanskrit text-which meant only that I would ask of it the kinds of questions that I had learned to ask from scholars and critics of Sanskrit literature, from Abhinavagupta to Shulman. It is incidental that the target poem, and the interpretive techniques, are both connected to South Asia: it is not as if, by asking these kinds of questions, I had somehow bridged the distance "between the text and the present."2 It is simply that I thought the techniques were powerful enough to address any text, and the text was capable of speaking back in any language in which it was thoughtfully addressed. What surprised me, although it should not surprise anyone who has read David Shulman's work, was this: upon exchanging myself, as a reader, for a cantankerous Sanskrit scholar of my own creation, Nammalvar suddenly opened up to me, as if to scoldingly remind me that the person reading his poem was not prior to imagination but constituted by it.

"Knowledge that is a lie." Can such a thing even exist? If something is a lie, it is not knowledge. Whoever speaks this short phrase must have once considered 
something to be true knowledge that he or she now considers to be false. And people generally only revise their beliefs in this way on the basis of new information. Thus, this phrase is a "narrative sentence": it hints that the speaker has undergone a profound change in belief as a result of some new circumstance. ${ }^{3}$ This first line leads us to read "bad living" and "foul body" in the same way: not just as negative evaluations, but as contradictions, and corrections, of a more positive evaluation of life and embodiment. What the addressee is asked to save us from is "all this"not just the epistemic, practical, and physical aspects of existence just referred to, but the kinds of painful experiences that have led the speaker to speak of them as being totally devoid of any redeeming qualities. Even before the addressee is identified as "Lord of the gods," we are told of two incredible things about him. First, it is with a certain purpose that he has been "born in this womb and that." The fact that he takes birth with purpose distinguishes him from all other beings, who are "born just to die, and die just to be born again." Second, that purpose is to save us from having to "suffer all this." The fact that he can save beings from the fate to which they are destined distinguishes him not just from all other beings, but all other gods as well. These opening lines thus show that the speaker's chosen deity deserves his title of "Lord of the gods."

We might expect the beginning of a composition to begin with an auspicious word or phrase. And, provided we stop after the word "knowledge," the beginning seems auspicious enough. But why, we might ask, would the speaker begin with three things that no reasonable person would want? The beginning of a poem often announces its theme. Lies, faithlessness, and physical torment-these are indeed thematic in the poem, not in themselves, but as consequences of love for Kannan. And if they necessarily accompany devotion to the "Lord of the gods," then perhaps it is not so inauspicious to begin with them. But it is not only the devotee who experiences these three things. In being born again and again, Kannan experiences them as well. And we have a clue that, among these three things, it is the "foul body" that is actually most important, in the speaker's request for Kannan to "hold fast to your body." It is the only word that is repeated in this first stanza. Embodiment is the condition of suffering, both ours and his, but it is also the condition of love-not the abstract love of the philosophers, but an experience that fills all of the domains of existence with which the poem begins, like blood returning painfully to the limbs after they have been battered numb by a cold and wet wind.

One more observation about the first stanza. What knowledge, specifically, is a lie? The speaker hints that for us, too, what had previously appeared as absolutely secure-the distinction between subject and object, and indeed the stable identity of the subject-will be undermined and eventually annihilated by what follows.

What the speaker had introduced as his "prayer" begins in the second stanza, where the speaker refers to a certain girl as "she" and "her." Those expressions, in general, are only used when their referent has previously been evoked in the discourse. ${ }^{5}$ In fact, she has not already been evoked. The speaker either presumes 
we know who she is already, or is deliberately keeping us in the dark. Well, who is she?

The characters of love poetry are often anonymous-he and she. Perhaps she is "she", the archetypal woman who despairs of her husband's return. There are certain indications the she lives in the world of literary conventions, such as the gathering rainclouds evoked as a standard of comparison at the end of the stanza. The monsoon, which makes travel impossible, will inevitably prolong her separation from her husband. And toward the end of the selection, the speaker comes very close to identifying her husband with him, the archetypal husband who "has gone away, gone many miles in search of wealth." But the speaker disavows this identification immediately after suggesting it by saying "or so it seems." We must find some other world, apart from or in addition to the world of literary conventions, in which the girl and her lover must be located.

Another possibility is that she is simply the poet, who is casting himself as a lovelorn woman in order to depict more sharply the nature of his devotion. But who is the poet anyway? All we can say is: there is a speaker; first-person pronouns are used. The use of "my" and "me" is exactly like that of "her" and "she": their referent ought to have already been evoked, but in fact it is not. Consider the third stanza, in which "my lonely heart" is separated from "me" both textually, through the intervention of several phrases, and narratively, since the final line presupposes that the speaker's heart is not within the speaker. If the speaker's heart sees something, does the speaker see it? And those women that the speaker's heart sees as external to itself-Earth, Splendor, "the gentle girl of the cowherds" - isn't it possible that one of these is the speaker, whose heart no longer knows how to recognize her? Identities are withheld, taken apart, made indistinct.

What remains distinct, however, is the way in which one relates to Kannan. We are told that that gods "bow low" to him, and that Earth and Splendor "follow him as a shadow." There is something special about this latter relation. A shadow cannot exist apart from that of which it is the shadow. The goddesses therefore have an existential dependency on Kannan. A shadow is also a fitting comparison because it is just there, independently of any will or desire. This prefigures Kannan's cruel indifference toward those who are devoted to him. But a third aspect of this comparison tends toward a very different conclusion. Gods, it is said, do not cast shadows. The fact that Kannan is said, even in a comparison, to have a shadow suggests the power of devotion to turn the "Lord of the gods" himself, whom we have just seen coursing the sky on the back of his bird, into a corporeal being.

Let us leave the girl with the dark curls in the second stanza for now. The poem itself has shifted from a third-person to a first-person perspective, as if the speaker's heart-disembodied at the beginning of the third stanza-has indeed made its way "home" to the speaker's body. Accordingly the subject shifts from observation to embodied experience. In the third stanza, the "cool sweet basil" and the "fiery discus" appeared more or less as ornamental epithets of Kannan. In the fourth 
and fifth, they take over the speaker's entire sensorium. From this point, Kannan's basil appears three times. First it stands in for the god himself, who assumes its "cool and fragrant," and thus ostensibly pleasant, qualities. Soon, however, the speaker describes being assaulted by a freezing wind, and hints that the reason for its coldness is that it has been "poisoned" by Kannan's basil. It is not merely that the speaker's evaluation of Kannan's qualities has changed. It is that the god is always described in terms of secondary qualities; that is, those whose character depends on the perceiving subject. ${ }^{6}$ Such qualities can be reaffirmed and redetermined on the basis of ongoing experience. And the experience described here is that of the sharp wind of rainy nights in mountain village, the kind that "steal[s] inside," gets inside one's clothes and bones, and makes one's breath as cold as the wind outside. By the time of the basil's third appearance, this time in the standard of a comparison, its coldness has stolen inside completely: for while the freezing wind has been transformed into a raging fire, the tears that the girl now cries are "cold as sweet basil." The speaker thus describes coldness as inhering in three things: first in Kannan's basil, its proper locus, then in the freezing wind, and finally in the girl's tears. This has a cumulative effect, suggesting that a frozen universe is inevitably closing in on the speaker, threatening to dissolve the boundaries of the self.

What underlies these transferences, the dynamic of externalization and internalization? Obviously, it is Kannan's solicitation of "the false and angry demoness." Once again, this phrase is used as if its referent has already been evoked. Perhaps it is well-known that Kannan consorts with a particular demoness. Perhaps this phrase simply designates some other woman, motivated by the speaker's jealousy of Kannan's attentions. Other women, of course, have already been mentioned in connection with Kannan: Earth, Splendor, "the gentle girl of the cowherds." But as we have already observed, the fact that they follow Kannan as a shadow hints at his passivity and indifference to them. Not so with the demoness. Kannan is said to actively "savor [her] nipples." Such an image of infidelity is guaranteed to steal inside and torture anyone who loves him. And it is the freezing wind that carries this image and forms a physical connection between the speaker, shivering in the mountains, with her faithless Kannan.

The jealousy that emerges from these lines, the "cold tears" that the girl weepsthey make sense so long as Kannan and the girl play the conventional roles of lover and beloved, her and him. But isn't he the "Lord of the gods"? Isn't it a mistake for the girl to feel such possessiveness over him? Doesn't the salvation of the world, in some sense, depend on Kannan's promiscuity, his ability to "give breath" to anyone who loves him? The poem has a clear answer here, which is hinted first by the shift from the first-person singular ("my lonely heart") to the first-person plural ("to freeze our very breath") over the course of the fourth stanza. The speaker's singularity, defined first in relation to the aloof Kannan, is deliberately eroded in the process of her being made aware, through the icy wind, of Kannan's presencewith another woman. And we, as readers, are implicated in this process, if only 
momentarily. For the poem then turns, once again, to the relationship between two individuals. The third-person perspective adopted in the fifth stanza has its customary omniscience: we can see the "wide-eyed girl" weeping, as we can never see ourselves, and we can see "the lord dark as freezing rain," whom the speakers of the previous stanza, suffering separation from Kannan, were not able to see. And hence we can see something else that those speakers could not: the twisting of Kannan's scepter, sure evidence of his betrayal.

"Look at her, look to your own lives inside this world." This statement not only punctures the third-person perspective cultivated in the previous stanza and forces us to see the girl as an externalization of ourselves. It also uses the form "this," indicating a world to which the speaker and the addressee both belong. Does "this world" exclude the world of literary convention, of her and him? Or does it inform us that our world is, in fact, the world we have been speaking of thus far, with icy windstorms that explode into flames? It is, in any case, the world in which we experience what the girl experiences. And what is that experience exactly? The coldness that has been alluded to again and again throughout the poem engenders a certain temporality. Anyone who experiences this kind of cold wants to escape from it, and therefore wishes for time to pass rapidly, while experiencing its passage as excruciatingly slow. This is the characteristic temporality of love-in-separation, a temporality that is nothing other than the theft of the present by the future.

This is the sense in which we should probably read the identification "she is Death": for death, too, is a future that robs the present. It is not that the girl is actually planning to seek revenge by killing Kannan, since he is not subject to death. The idea, rather, must be that the girl's prospective union with Kannan has the qualities of a death by ambush —its inevitability, its finality, and its rapidity and violence. These qualities contrast with the calm and domestic union that the speaker had previously envisioned with her own heart ("it might come home to me"). The girl does not, at this moment, follow Kannan "as a shadow." It is not, then, that we pass our time in the rainy season of existence waiting passively for Kannan to "give us breath." If we cry tears "cold as basil" after enduring Kannan's indifference, if that despair drives us to active and violent rage, then we might surprise the god, confront him with his misdeeds, and make him our own - not in the sense that he belongs to no others, but in the sense that he no longer escapes us. 